\title{
CASE STUDY ON COMPETENCE BASED APPROACH IN COURSE "MATHEMATICS FOR ECONOMISTS"
}

\author{
Anna Vintere ${ }^{1}$, Mg.Math \\ Department of Mathematics, Latvia University of Life Sciences and Technologies
}

\begin{abstract}
This paper is the result of scientific analysis and assessment of scientific literature and a number of information sources taking into consideration the author's reflection experience and observations on competencybased approach in higher education seeing competence as key element of sustainable development. The competence to be acquired in the study process is reflected in the learning outcomes that describe three major domains: knowledge (learning to know), skills (learning to do) and competences (learning to be). The aim of the article is to analyse the course "Mathematics for Economists" in relation to the dimensions of competence-based education, to determine the extent to which the course corresponds to the characteristics of education for sustainable development. For that reason, in this article is given short summary on the course "Mathematics for Economists" which include the aim of this course, expected learning outcomes as well as the conception of mathematics studies for economists and business managers and made course analysis by four dimensions: contextual learning, interdisciplinary learning, problem-solving and critical thinking. The results show that the course is an example of good practice in transforming mathematics studies into education for sustainable development.
\end{abstract}

Key words: higher education, competence, critical thinking, mathematics for economists, problem solving. JEL code: available on: I210.

\section{Introduction}

The competence-based approach in higher education is the main challenge of today and the development trend in higher education in Latvia. Higher education through the competence-based education interact with the labour market as well as respond to the requirements of sustainable development of society.

In Latvia, with term "competence" is understood necessary knowledge, professional experience, comprehension in a specific field of problem, and a skill to use knowledge and experience in a particular action (Par termina kompetence ..., 2009).

The European Commission (EC) documents deal with the issue of competence by identifying different key competences, each of which contributes to a successful life in society (EC, 2006; 2018). Key competences include skills such as critical thinking, problem solving, teamwork, communication and negotiation skills, analytical skills, creativity and intercultural skills (EC, 2018).

One of the most frequently mentioned competencies mentioned above in literature are analytical skills such as critical thinking and problem-solving. In the 2016 World Economic Forum, these competences were identified as one of the ten skills needed for future employment (World Economic Forum, 2016). Also, a study conducted by employers in the United States shows, problem-solving skills and critical thinking are one of the important skills needed by young people entering the labour market (The Conference Board, 2006). In turn, the World Economic Forum 2018 drew attention to the growing demand for specialists with developed logical and analytical thinking as well as increased demand for mathematics education (World Economic Forum, 2018).

Mathematics role in sustainable development is characterized by a number of factors, including, mathematical competence compliance with competencies for sustainable development. The mathematics studies at university develop the cognitive abilities of a person, influence studies of special subjects as well as contribute to the development of professional competence ensuring highly qualified specialists for the knowledge-based, skill and technology-intensive industries. In turn, Tsafe

${ }^{1}$ Corresponding author: tel.: +371 29419351, e-mail address: Anna.Vintere@llu.Iv 
A.K. (2013) points to the role of mathematics in promoting entrepreneurial skills, thus contributing to poverty alleviation. He points out that using mathematical skills, the entrepreneurs are able to understand and master the commercial skills, bargaining power, exchange rates etc. (Tsafe A.K., 2013).

In view of the above-mentioned aspects, the object of the study is a course "Mathematics for Economists" in the context of education for sustainable development. The aim of the article is to analyse the course "Mathematics for Economists" in relation to the four dimensions of competencebased education: contextual learning, interdisciplinary learning, problem-solving and critical thinking, to determine the extent to which the course corresponds to the characteristics of education for sustainable development.

\section{Methodology}

The article is the result of scientific analysis and assessment of scientific literature and a number of information sources taking into consideration the author's reflection experience and observations in connection with the development and implementation of the curriculum in mathematics.

There are a number of studies in the scientific literature that examine competences as key elements of sustainable development. The concept of competence is seen as an essential guide to orientate teaching and learning to sustainable development of society. Education has a responsibility to be in gear with 21st century challenges and aspirations, and foster the right types of values and skills that will lead to sustainable and inclusive growth (UNESCO, 2017). Education for Sustainable Development (ESD) is the education, teaching and learning required to ensure social, economic and ecological wellbeing now and into the future (Sterling S., 2012; UNESCO, 2017). Based on UNESCO (2017) documents, the principles of ESD include: inter-disciplinarity; value-driven; critical thinking and problem solving; participatory decision-making; and applied learning which is relevant and culturally appropriate to local and other contexts. The researches regarding ESD prove that students need to develop sustainable skills: problem solving using holistic and systemic approaches, making critical judgements on real life issues, applying theory to practice and vice versa, and working collaboratively and in interdisciplinary teams (Dawe G., Jucker R. and Martin S., 2005; Parkin S. et al., 2004).

Based on the analysis of scientific literature as well as national and European documents regarding higher education and also sustainable development in the article is made course "Mathematics for Economists" analysis by four dimensions: contextual learning, interdisciplinary learning, problemsolving and critical thinking, which are most often cited in scientific literature as key elements of education for sustainable development.

In this article based on publicly available information is also given short summary on the course "Mathematics for Economists" which include the aim of this course, expected learning outcomes as well as the conception of mathematics studies for economists and business managers.

\section{Research results and discussion}

The course "Mathematics for Economists" at the Latvia University of Life Sciences and Technologies is compulsory in two study programs: the professional higher education bachelor study program "Entrepreneurship and Business Management" at the volume of 3 ECTS and the academic education bachelor study program "Economics" at the volume of 6 ECTS. Aim of the course: to acquire mathematical knowledge and practical skills necessary for the acquisition of further special subjects, as well as to get familiar mathematical application in research of various economic relations. 
In accordance with Latvian legislation, the competence to be acquired in the study process is usually reflected in the learning outcomes (Augstskolu likums, 2011). According to UNESCO learning outcomes are understood as statements that describe three major domains: knowledge (learning to know), skills (learning to do) and competences (learning to be) (UNESCO, 2015) and this approach through knowing, doing and being reflects the mission of future specialists to prefer the direction of sustainability. The learning outcomes of the course "Mathematics for Economists" also are described indicating the knowledge, skills and competence to be achieved during the studies of this course. The knowledge includes subjects from different part of mathematics: knowledge on elements of linear algebra, limit of function, differential calculus and integral calculations, as well as a critical understanding of their possibilities for solving economic problems.

At Latvia University of Life Sciences and Technologies skills to be acquired by students in the framework of course "Mathematics for Economists" are described by key words: to identify, solve, calculate, find, create, explore, apply, etc. At the end of the course students have to perform operations with matrices; to solve linear equation systems; calculate limit of functions; find a derivative of functions; use derivatives to explore the function; to find the partial derivatives of the two-variable function; find the two-variable function extreme; integrate functions; apply mathematical knowledge in economics, make various financial calculations etc.

According to the European Union documents, the competence-based learning of mathematics as a result of the study process involves eight mathematical competences (Niss M., 2003; OECD, 2009). Seven of them are indicated as a results of the course "Mathematics for Economists": mathematical thinking, handling symbols and formal mathematics language, mathematical problem formulating and solving, reasoning, modelling (ability analyse and build mathematical models concerning other area), aids and tools (ability to make use of and relate to the aids and tools of mathematics, including information technologies), communication (ability to communicate in, with and about mathematics). The development of the eighth competence "representing mathematical entities" is ensured by developing other competencies.

At Latvia University of Life Sciences and Technologies, the content of mathematics programmes is divided into three modules: engineering, bio-sciences, and social sciences. These modules consist of content, skills and application. Content module relates to proofs: from the simplest proofs for engineering to only conclusion or algorithms for social sciences. There are also three level of skills find, interpret and explain for engineers, solve and explain for bio-sciences and solve by algorithm for social sciences. Application in the engineering speciality is only an illustration, but for social sciences - the entire attention is devoted to the solution of practical problems. Therefore, the main focus of mathematics studies for economists and business managers is to providing conclusions algorithms of applied nature and entire attention is devoted to the solution of practical problems, so developing the ability to analyse and build mathematical models as well as cope with the mathematical language and its tools.

This conceptual approach to teaching mathematics is in line with the economist profession standard and the business manager's profession standard in Latvia, which determines that these professions require mathematical knowledge for the performance of the basic tasks of professional activity, which is also the above-mentioned aim of this study course. It should be noted that his description justifies the contextual approach of the course. Contextual approach usually is associated by the content-studied with the real-world situations of students. It encourages students to make 
connections between the knowledge possessed by its application in their lives. As described above, with this approach, the outcome of learning is expected to be more meaningful for students.

According to the "Learning for a Sustainable Future" (2008), an interdisciplinary approach to teaching blurs the lines between subject boundaries. Interdisciplinarity usually is understood as usage of knowledge and methods of different disciplines and ability to work on complex problem in interdisciplinary context (LozaNo et al., 2017). The title "Mathematics for Economists" indicates that this course is interdisciplinary and covers two branches of science: mathematics and economics with a focus on microeconomics and finance. The split of these two sets are: economic functions, market equilibrium, function differentiation and interpretation in economy, the use of a derivative in the studies of economic relationships: elasticity, marginal functions, maximization of the profit and cost minimization, economic-mathematical regularities for the benefit of two farms, indefinite integral application to determine production costs, revenues and profits, definite integral applications for determining resource consumption, output / volume of goods and economic indicators, basis of financial mathematics.

The problem-based learning is one of the most often in scientific literature discussed strategy which responds to many challenges that higher education is facing. A.Steinemann (2003) associates problem-based learning with the development of students' abilities needed for sustainable development such as flexible, integrative, multidisciplinary problem-solving rather than singular solutions. In problem-based learning, there is emphasized the value of working on complex, realworld problems for students to develop knowledge, skills and competencies (LozaNo et al, 2017). In the course "Mathematics for Economists", problem-based approach can be viewed by two directions: learning the real world problems that students will encounter as professionals (as described above) as well as building problem-solving skills. Mathematics is seen as one of the main subject for developing problem solving skills. According to Berry (2002), problem solving in mathematics is taught in three ways: pure mathematics investigation activities, mathematical modelling and solving real life problems. The course "Mathematics for Economists" contributes to the development of ability to perform active modelling. Studying mathematics students should be able to develop new mathematical knowledge through problem-solving, solve problems arising in mathematics and other contexts, apply and adapt various appropriate strategies to solve problems and monitor and analyse the problem of mathematical processes (Berry J., 2002). The process of problem solving include "understanding of the problem situation and its step-by-step transformation, based on planning and reasoning" (Finegold D., Notabartolo A.S., 2016). Here is a clear connection between the mathematics problem solving and problem-solving models that include problem analysis, decision making on desired / potential solution, and solution implementation and verification. Problem solving steps in mathematics: identification of the problem, interpretation of the problem (to translate it into mathematical language and select appropriate tools or formulas), problem analysis (apply general problem to a specific situation), modelling the problem solving using the deduction method, solving the problem and checking the answer (Zeidmane A., Rubina T., 2018).

The second most important analytical competence is critical thinking. In the context if sustainable development, critical thinking is understood as ability to challenge norms, practices and opinions. It includes also reflection on one's own values, perceptions and actions, as well as it is understanding of external perspectives (LozaNo R. et al., 2017). Critical thinking is very close to problem-solving skills, but more focused on "information identification and interpretation, information analysis and evaluation of evidence and argument" (Firdaus F. et al., 2015). Thinking critically requires students 
to acquire, process, interpret, rationalize and critically analyse large volumes of conflicting information to the point of making an informed decision and taking action in a timely fashion (C21, 2012).

There are three components of critical thinking: identification and interpretation of information, information analysis, evaluation of evidence and argument (Zeidmane, Rubina, 2018). In the course "Mathematics for Economists", critical thinking is promoted by solving various tasks, and the results obtained by students must always be interpreted (component of interpretation of information). Component of identification can be characterised by two examples.

- If a students have to calculate a third-order determinant whose row or column contains zero, then they have to critically evaluate which determinants calculation method is used, because in this case it is possible to either expand along the row or column where the zero is located, or based on properties get a second zero in this row or column.

- There is given the case when the factory produces four types of candies. The quantity of ingredients required for the producing of each type of candy also are given. Using the information about quantity of raw materials used for making 1 ton of candies, students have to get solution for two different situations: (1) how much of each ingredients are needed to produce a certain amount of candies (to fulfil the order) and (2) determine how much each type of candy could be produced in order to fully utilize all the given raw materials.

Critical thinking component of information analysis can be characterized bay task:

"Given the demand function of the product $A$, where $x$ - price of the product $A$, but $y$ - price of the product $B$. And given the selling prices at the moment. How will change the demand of the product $A$ if: (1) The price of the product $A$ increases by one unit; (2) The price of the product $A$ is increased by $1 \%$, but the price of the product $B$ does not change; (3) The price of the product $B$ increases by one unit; (4) The price of the product $B$ is increased by $1 \%$, but the price of the product A does not change?"

\section{Acknowledgement}

The paper was supported by grant from Latvia University of Life Sciences and Technologies program's "Strengthening the Scientific Capacity in the Latvia University of Life Sciences and Technologies" no. Z32 entitled "Development of the didactical model for transforming mathematics studies into education for sustainable development".

\section{Conclusions, proposals, recommendations}

1) The research results show that the course "Mathematics for Economists" at the Latvia University of Life Sciences and Technologies corresponds to the characteristics of education for sustainable development. In the course at least three ESD pedagogical approaches are used: contextual learning, interdisciplinary learning, problem-based learning. The course contributes to the development of analytical skills necessary for sustainable development such as problem solving skills and critical thinking.

2) The contextual approach of the course characterizes by the course objectives as well as by the economist profession standard and the business manager's profession standard in Latvia, which determines mathematical competence for these professions.

3) "Mathematics for Economists" is interdisciplinary course and covers two branches of science: mathematics and economics with a focus on microeconomics and finance. 
4) The problem-based approach characterised by working on real-world problems so develop knowledge, skills and competencies necessary for sustainable development. The description of the connection between the mathematics problem solving and different problem-solving models also are given.

5) In the course "Mathematics for Economists", critical thinking, which includes identification and interpretation of information, information analysis, evaluation of evidence and argument, is promoted by solving various tasks.

6) The course is an example of good practice in transforming mathematics studies into education for sustainable development.

7) The study shows that the course "Mathematics for Economists" corresponds to the characteristic of competence-based education.

\section{Bibliography}

1. Augstskolu likums. (Law of Instituions of Higher Education), 2011, Riga: Saeima.

2. Berry, J. (2002). Developing Mathematical Modelling Skills: The Role of CAS. Retrieved: https://link.springer.com/article/10.1007\%2fbf02655824

3. C21 Canada (2012). Shifting Minds: A 21 $1^{\text {st }}$ Century Vision of Public Education for Canada. Retrieved: www.c21canada.org/wp-content/uploads/2012/11/Shifting-Minds-Revised.pgf

4. Dawe, G., Jucker, R., and Martin, S. (2005). Sustainable Development in Higher Education: Current Practice and Future Developments. A report for the Higher Education Academy: York.

5. EC (2006) Recommendation of the European Parliament and of the Council of 18 December 2006 on key Competences for Lifelong Learning (2006/962/EC). Official Journal of the European Union, L394, 30 December 2006, pp. 10-18. Retrieved: http://eur-lex.europa.eu/legalcontent/EN/TXT/?uri=celex:32006 H0962

6. EC (2018). Annex to Proposal for a Council Recommendations on Key Competences for Life-long Learning. $A$ European Reference Framework (2018) Retrieved: https://eurlex.europa.eu/resource.html?uri=cellar:395443f6-fb6d-11e7-b8f501aa75ed71a1.0001.02/DOC_2\&format=PDF

7. Finegold, D., Notabartolo, A.S. (2016). 21st-Century Competencies and Their Impact: An Interdisciplinary Literature Review. Executive Summary. Retrieved: https://hewlett.org/wpcontent/uploads/2016/11/21st_Century_Competencies_Impact.pdf

8. Firdaus, F., Kailani, I., Bakar, N.B., Bakry, B. (2015). Developing Critical Thinking Skills of Students in Mathematics Learning. Journal of Education and Learning, vol.9, No 3, pp.226-236, 2015. Retrieved: https://www.researchgate.net/publication/282526043_Developing_Critical_Thinking_Skills_of_Students_in_ Mathematics_Learning

9. Lozano, R., Merrill, M.Y., Sammalisto, K., Ceulemans, K., LozaNo F.J. (2017). Connecting Competences and Pedagogical Approaches for Sustainable Development in Higher Education: A Literature Review and Framework Prpposal. Sustainability, 2017, 9, 1889. www.mdpi.com/journal/sustainability

10. Niss, M. (2003). Mathematical Competencies and the Learning of Mathematics: The Danish KOM project. Mediterranean Conference on Mathematics Education, Athens, Greece: Hellenic Mathematical Society and Cyprus Mathematical Society, 2003, pp. 115-124.

11. OECD (2009). Assessment Framework - Key Competencies in Reading, Mathematics and Science. Retrieved: www.oecd.org/dataoecd/11/40/44455820.pdf

12. Parkin, S., Johnson, A., Buckland, H. and White, E. (2004). Learning and Skills for Sustainable Development: Developing a Sustainability Literate Society. HEPS, London, 2004.

13. Par termina kompetence izpratni un lietosanu latviesu valoda. LZA Terminologijas komisijas lemums Nr.84, 2009. (On the usage of the term competence in the Latvian language). Retrieved: https://likumi.Iv/ta/id/203798-par-termina-ikompetencei-izpratni-un-lietosanu-latviesu-valoda.

14. Steinemann, A. (2003). Implementing Sustainable Development through Problem-based Learning: Pedagogy and Practice. Journal of Professional Issues in Engineering Education and Practice, 129, $216-224$.

15. Sterling, S. (2012). The Future Fit Framework - an Introductory Guide to Teaching and Learning for Sustainability in HE. Higher Education Academy, York.

16. The Conference Board (2006). Are They Really Ready to Work? Employers' Perspectives on the Basic Knowledge and Applied Skills of New Entrants to the 21st Century U.S. Workforce. The Conference Board, 2006. Retrieved: https://files.eric.ed.gov/fulltext/ED519465.pdf

17. Tsafe A. K. (2013). Mathematics Literacy: An Agent of Poverty Alleviation and National Development. Journal of Education and Practice. Vol. 4, No 25, pp. 51- 54. Retrieved: http://www.iiste.org/Journals/index.php/JEP/issue/view/897

18. UNESCO (2015). Level-setting and Recognition of Learning Outcomes. The use of level descriptors in the twenty-first century. UNESCO, 2015, 203 p. Retrieved: http://unesdoc.unesco.org/images/0024/002428/242887e.pdf 
19.UNESCO (2017). Education for Sustainable Development Goals: Learning Objectives. Retrieved: https://unesdoc.unesco.org/ark:/48223/pf0000247444

20.UNESCO (2017). Textbooks for Sustainable Development. A Guide to Embedding. UNESCO MGIEP, 186 p. Retrieved: http://unesdoc.unesco.org/images/0025/002599/259932e.pdf

21. World Economic Forum (2016) The Future of Jobs Employment, Skills and Workforce Strategy for the Fourth Industrial Revolution. Global Challenge Insight Report. Retrieved: http://www3.weforum.org/docs/WEF_Future_of_Jobs.pdf.

22. World Economic Forum (2018). Creating a Shared Future in a Fractured World. World Economic Forum Report. Retrieved: http://www3.weforum.org/docs/WEF_AM18_Report.pdf

23. Zeidmane A., Rubina T. (2018). Problem in Development of Problem Solving Skills of Studying Mathematics at the Latvia University of Life Sciences and Technologies. Proceedings of ICERI2018 Conference, 12th-14th November 2018, Seville, Spain, 6181-6188. 